\title{
About the emissions of alternative jet fuels
}

\author{
Marina Braun-Unkhoff ${ }^{1}\left(\right.$ ib $\cdot$ Uwe Riedel $^{1} \cdot$ Claus Wahl $^{1}$
}

Received: 23 March 2016/Revised: 4 November 2016/ Accepted: 30 November 2016/Published online: 19 December 2016

(C) Deutsches Zentrum für Luft- und Raumfahrt e.V. 2016

\begin{abstract}
In the last years, several alternative aviation jet fuels have been approved as a response to worldwide concerns on adverse environmental effects of greenhouse gas emissions. However, comprehensive emissions studies are not part of the approval process. When burning a jet fuel, the exhaust gases are a mixture of gaseous specious including aromatics and non-gaseous species, particles, and soot. In addition, these species may affect the growth and lifetime of contrails known to be of influence on the climate due to their radiative forcing. Within this context, the use of synthetic aviation fuels may offer several advantages, going beyond reduced $\mathrm{CO}_{2}$ emissions. These issues were addressed by studying the combustion of synthetic jet fuels taking into account their individual composition. An overview of what is known on their emission pattern was presented. Mostly, the same general trends were reported for the emissions of interest, for the fuels considered and at the power settings selected, with no adverse emissions effects. In particular, less soot particle emissions were reported, in mass and in number concentration, for GtL, HEFA, and farnesane. Moreover, a strong link between the amount and type of aromatics content of a jet fuel and soot emissions was observed.
\end{abstract}

Keywords Alternative aviation fuels - Combustion . Emissions $\cdot$ Particles $\cdot$ Soot $\cdot \mathrm{NO}_{x}$

This paper is based on a presentation at the German Aerospace Congress, September 22-24, 2015, Rostock, Germany.

Marina Braun-Unkhoff

marina.braun-unkhoff@dlr.de

1 Institute of Combustion Technology, German Aerospace Center (DLR), Pfaffenwaldring 38-40, 70569 Stuttgart, Germany

\section{Introduction}

Growing concerns about the security of supply, as well as negative effects on the environment and climate are the main drivers for worldwide efforts and initiatives to decouple energy generation from crude oil [1,2].

Within the aviation sector, an increasing interest exists in the development of new jet fuels, as an alternative to Jet A/A-1 the only jet fuels worldwide available since decades [3]. Thus, the aviation sector is joining the efforts combating climate change by reduction of greenhouse gas (GHG) emissions, in particular carbon dioxide $\left(\mathrm{CO}_{2}\right)$, and ensuring security of supply.

The efforts for developing and using alternative aviation fuels were also triggered by major stakeholders [4-6] and policy packages worldwide [7, 8]. E.g., IATA, the International Air Transport Association, has committed to the vision of carbon neutral growth starting 2020 and to halve emissions by 2050 compared to 2005-levels [4]. ACARE, the Advisory Council for Aeronautical Research in Europe, has announced their goal of reducing $\mathrm{CO}_{2}$ emissions by $50 \%$ in 2020 and by $75 \%$ by 2050 related to year- 2000 aircraft [5] (Table 1). The 'Flightpath 2050' EC-initiative [6] aims at a $75 \%$ reduction in $\mathrm{CO}_{2}$ emissions and $90 \%$ reduction in nitrogen oxide $\left(\mathrm{NO}_{x}\right)$ emissions, per passenger kilometer.

In 2010, about 53 million tons of kerosene were consumed in Europe; about 20 million tons by the largest three European airlines (AF/KLM group, BA, and Lufthansa group). The demand for kerosene will increase because a continuous annual growth of air transport is predicted, for passengers and freight [1]. Consequently, the amount of emissions will not go down despite the success already achieved, such as the partially decoupling of kerosene consumption and air traffic growth or the reduction of the 
Table 1 ACARE emission targets-environmental focus [1, 4]

\begin{tabular}{|c|c|c|c|}
\hline \multirow[t]{3}{*}{ Target } & \multicolumn{3}{|c|}{ Reduction in $\%$ related to year-2000 aircraft } \\
\hline & \multicolumn{2}{|c|}{ By 2020 [7] } & \multirow[t]{2}{*}{ By $2050[5$} \\
\hline & & Engine & \\
\hline $\mathrm{CO}_{2}$ & 50 & $15-20$ & 75 \\
\hline $\mathrm{NO}_{x}$ & 80 & 80 & 90 \\
\hline Noise & 50 & $10 \mathrm{db}$ & 65 \\
\hline
\end{tabular}

average fleet consumption of kerosene, currently about $3.8 \mathrm{~L}$ per passenger per $100 \mathrm{~km}$.

It is clear that only a significant contribution of lowcarbon fuels can make these ambitious goals become true, in addition to the reductions in specific emissions from the continuing improvements in technology (which new aircrafts will benefit from), air traffic management, and operational procedures [9].

Synthetic jet fuels can be made from various nonpetroleum feedstocks, such as coal, gas, biomass including waste, or industrial byproducts.

At present, five different kinds of alternative jet fuels are available. These synthetic kerosenes are certified following the ASTM and DefStan protocols [10,11], so that they are allowed for regular passenger flights. Note that they can only be used in blends, up to $50 \%$ depending on the kind of synthesized fuel, with Jet A-1, besides the so-called Fully Synthetic Jet Fuel (FSJF) produced from Sasol. An overview is given in [12-14]. The technical feasibility, as well as the compatibility of alternative jet fuels with today's planes and fuel logistic has been proven [15-29].

However, advanced biofuels are the only low-carbon option (reducing $\mathrm{CO}_{2}$ ) to substituting kerosene [2, 7, 9]. The commercialization of aviation biofuel deployment will need to speed up, to be able to timely provide the amounts needed.

As a consequence, the European Commission (EU) has launched, in 2011, the 'European Advanced Biofuels Flight Path 2020'; the goal is to integrate an annual production of two million tons into the EU civil aviation sector by 2020 . In 2011, the aviation initiative for renewable energy in Germany (aireg) started as a platform for promoting sustainable jet fuel development [30] aiming at replacing $10 \%$ of the kerosene demand in Germany by sustainable aviation fuels till 2025.

However, the impact of aviation emissions is much wider and going beyond $\mathrm{CO}_{2}$. When burning a jet fuel, a mixture consisting of numerous species [3, 13, 14, 31], the exhaust gases are a mixture of several species. These emissions released at ground level (airport) and at flight level may affect the local air quality, as well as the climate. The use of synthetic fuels might offer several advantages as for bio-kerosene due to their specific composition that is differing from the one of Jet A-1. For example, due to the lack of aromatics in many neat alternative jet fuels, a reduced effect on contrail formation and climate impact is envisaged, compared to Jet A-1. This aspect was addressed in [32], with necessary research steps to close these gaps pointed out.

In the present paper, the potential effects of aviation emissions from alternative fuels are considered compared to the ones of Jet A-1. First, the emissions of an aircraft and their environmental effects are described, also referring to where released (at ground or flight level). Subsequently, the combustion of alternative fuels is considered by taking into account their individual composition. Finally, experimental findings when burning these new aviation fuels, as well as insights gained from modeling are presented, mostly gathered from literature.

\section{Principle aircraft emissions: background}

The present study is aimed at summarizing the current knowledge on the effects on emissions when burning alternative jet fuels which are composed of numerous hydrocarbons. Type and concentration of emissions may depend on the fuel/air ratio, the temperature, as well as the power setting, besides the specific jet fuel's composition.

\subsection{Emissions}

In general, the main products of combustion are by far $\mathrm{CO}_{2}$ and water $\left(\mathrm{H}_{2} \mathrm{O}\right)$, but also nitrogen oxides $\left(\mathrm{NO}_{x}\right)$, sulfur containing species $\left(\mathrm{SO}_{2}\right)$, unburned hydrocarbons (UHC) including aromatic species and other precursors of particles and soot as shown in Fig. 1. A schematic diagram describing major pathways from fuel-break-up, aromatics to PAH and soot particles is given in Fig. 2; for details see [34-38].

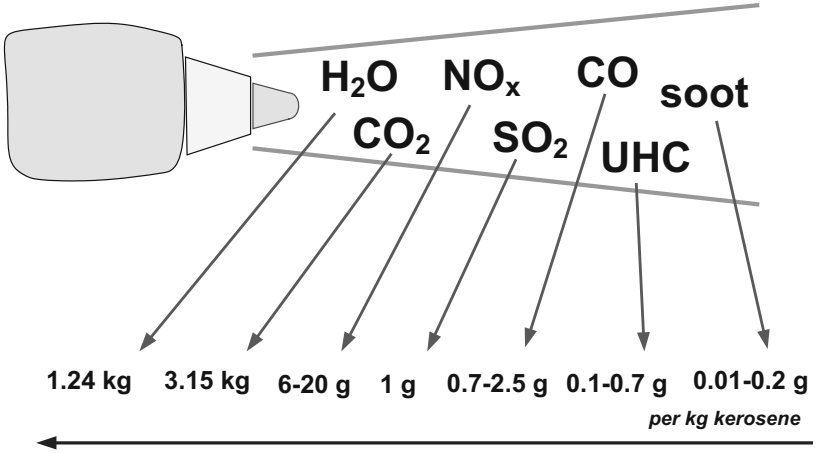

amount of emissions

Fig. 1 Major emissions when burning kerosene in a jet engine [33] 


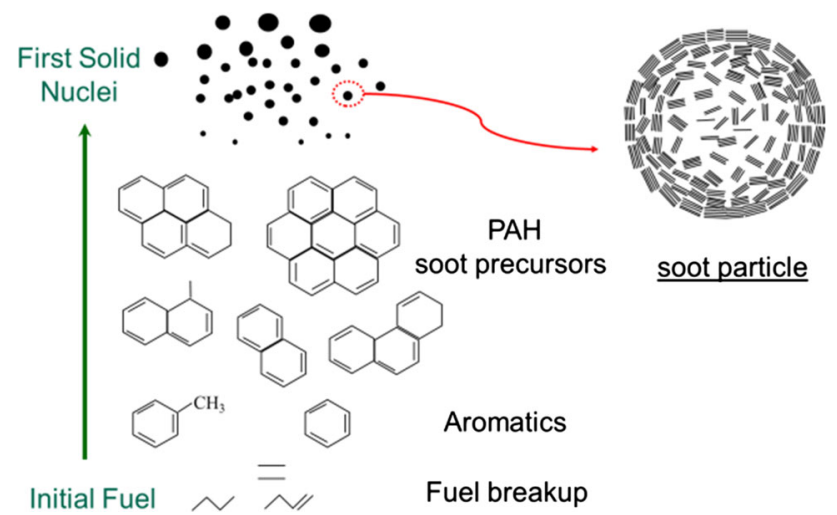

Fig. 2 Soot formation-schematic sketch [37]

For a stoichiometric mixture and an ideal and complete combustion (no pollutants), $\mathrm{CO}_{2}$ and water are the only products, besides energy released. Hence, the higher the heating value of a specific aviation fuel, the lower the amounts of $\mathrm{CO}_{2}$ produced for a given thrust and the lower a fuel's contribution to global warming. In addition, the higher the $\mathrm{H} / \mathrm{C}$ ratio, the higher the amount of water released:

$\mathrm{C}_{x} \mathrm{H}_{y}+(x+0.25 y) \mathrm{O}_{2}=x \mathrm{CO}_{2}+0.5 \mathrm{yH}_{2} \mathrm{O}+$ energy.

However, real combustion processes are never ideal leading to the formation of additional pollutants: $\mathrm{CO}$, aromatics (PAH), unburned hydrocarbons (UHC), and soot, if the fuel is burned under excess of fuel (fuel rich, $\varphi>1$; corresponding to $\lambda<1$ ); oxygen rich species such as ketones, peroxides, and nitrogen oxides are emitted, if the fuel is burned under excess of air $(\varphi<1$; corresponding to $\lambda>1)$.

Furthermore, the emissions spectrum is dependent on the flame temperature. Usually, the maximum of the flame temperature of a hydrocarbon flame is occurring for slightly fuel rich mixtures. For all other fuel-air ratios, the flame temperature is much lower. Once, the temperature will become lower and lower, radical termination steps, such as $\mathrm{H}+\mathrm{O}_{2}=\mathrm{HO}_{2}$, instead of radical branching reactions, e.g. $\mathrm{H}+\mathrm{O}_{2}=\mathrm{O}+\mathrm{OH}$, will become more and more dominant. As a result, reactive radicals, i.e., $\mathrm{H}, \mathrm{O}$, and $\mathrm{OH}$, cannot be produced fast enough in the concentrations needed to sustain the laminar flame speed; a blowout of the flame will be observed [39]. For hydrocarbons, a critical temperature is around $1100 \mathrm{~K}$, at ambient pressures [39].

In addition, emissions depend on the different flight operations (power settings), as shown schematically in Fig. 3. The power settings used during the LTO-cycle (landing-takeoff, ICAO): Taxi, approach, climb, and takeoff, corresponding to $7,30,85$, and $100 \%$ thrust, respectively.

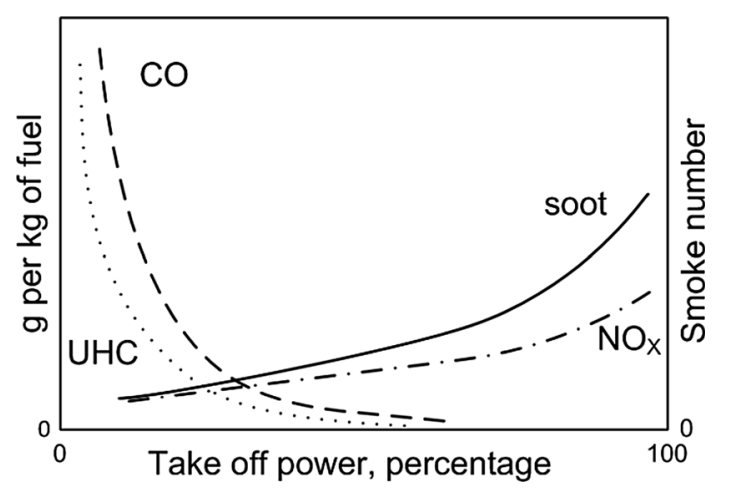

Fig. 3 Emissions characteristics in an aircraft engine, principle power dependency [40]

The following general tendencies exist:

- $\mathrm{CO}_{2}$ and $\mathrm{H}_{2} \mathrm{O}$ : Proportional to fuel combustion.

- $\mathrm{H}_{2} \mathrm{O}$ : The higher the $\mathrm{H} / \mathrm{C}$ ratio, the higher the amount of water released.

- Sulfur oxides: Proportional to amount of sulfur (S) within the fuel.

- UHC, $N O_{x}, C O$ : Dependent on the combustion parameters (temperature $T$, pressure $p$, turbulence level, residence time $t$ ) within the jet engine.

- $C O$ and UHC: High at idle and taxi

- $N O_{x}, P M$ (particulate matter), soot: High at take-off, climb.

\subsection{Environmental effects of emissions}

Having identified the relevant aircraft engine emissions, their environmental effects need to be considered. The relevant data of the most important atmospheric greenhouse gases are given in Table 2.

All species are emitted either at ground (airport) or during flight (flight level), into the lower stratosphere and into the upper troposphere. Thus, they may alter the concentration of atmospheric greenhouse gases, as well as the earth's radiative forcing (RF) constant.

Large differences exist in the species atmospheric residence time (Table 2). This affects the impact of aircraft on climate. A long atmospheric residence time of a species (e.g., $\mathrm{CO}_{2}$ and $\mathrm{CH}_{4}$ ) will result in a well-mixed distribution throughout the atmosphere; this means, the effects of the aircraft emissions cannot be distinguished from those emitted by any other source after some time. Species with shorter atmospheric residence times (e.g., $\mathrm{H}_{2} \mathrm{O}, \mathrm{NO}_{x}, \mathrm{SO}_{x}$, and particles) remain concentrated near flight routes, in the northern mid-latitudes, in particular. In summary, some emissions can lead to radiative forcing that is regionally located near the flight routes for some components (e.g., contrails) in contrast to emissions that are globally mixed (e.g. $\mathrm{CO}_{2}$ and $\mathrm{CH}_{4}$ ). 
Table 2 Important atmospheric gases-global warming potential (GWP) relating to $\mathrm{CO}_{2}$, atmospheric lifetime, and contribution to global warming $(\mathrm{GW})$, with and without consideration of $\mathrm{H}_{2} \mathrm{O}$ [41, 42]

\begin{tabular}{|c|c|c|c|c|c|}
\hline \multirow[t]{2}{*}{ Species } & \multicolumn{2}{|c|}{ GWP time horizon } & \multirow[t]{2}{*}{ Atm. lifetime } & \multicolumn{2}{|c|}{ Contribution to GW } \\
\hline & 20 year & 100 year & & $\mathrm{w} / \mathrm{H}_{2} \mathrm{O}(\%)$ & w/o $(\%)$ \\
\hline $\mathrm{H}_{2} \mathrm{O}$ & $\mathrm{n} / \mathrm{a}$ & $\mathrm{n} / \mathrm{a}$ & 9 day & $36-72$ & - \\
\hline $\mathrm{CO}_{2}$ & 1 & 1 & 100 years & $9-26$ & 60 \\
\hline $\mathrm{CH}_{4}$ & 72 & 25 & 12 years & $4-9$ & 20 \\
\hline $\mathrm{N}_{2} \mathrm{O}$ & 289 & 298 & 114 years & $<5$ & $<5$ \\
\hline Aerosols & $\mathrm{n} / \mathrm{a}$ & $\mathrm{n} / \mathrm{a}$ & $\mathrm{n} / \mathrm{a}$ & $<5$ & $<5$ \\
\hline
\end{tabular}

Fig. 4 Aviation radiative forcing (RF) components in 2005; LOSU level of scientific understanding [43]

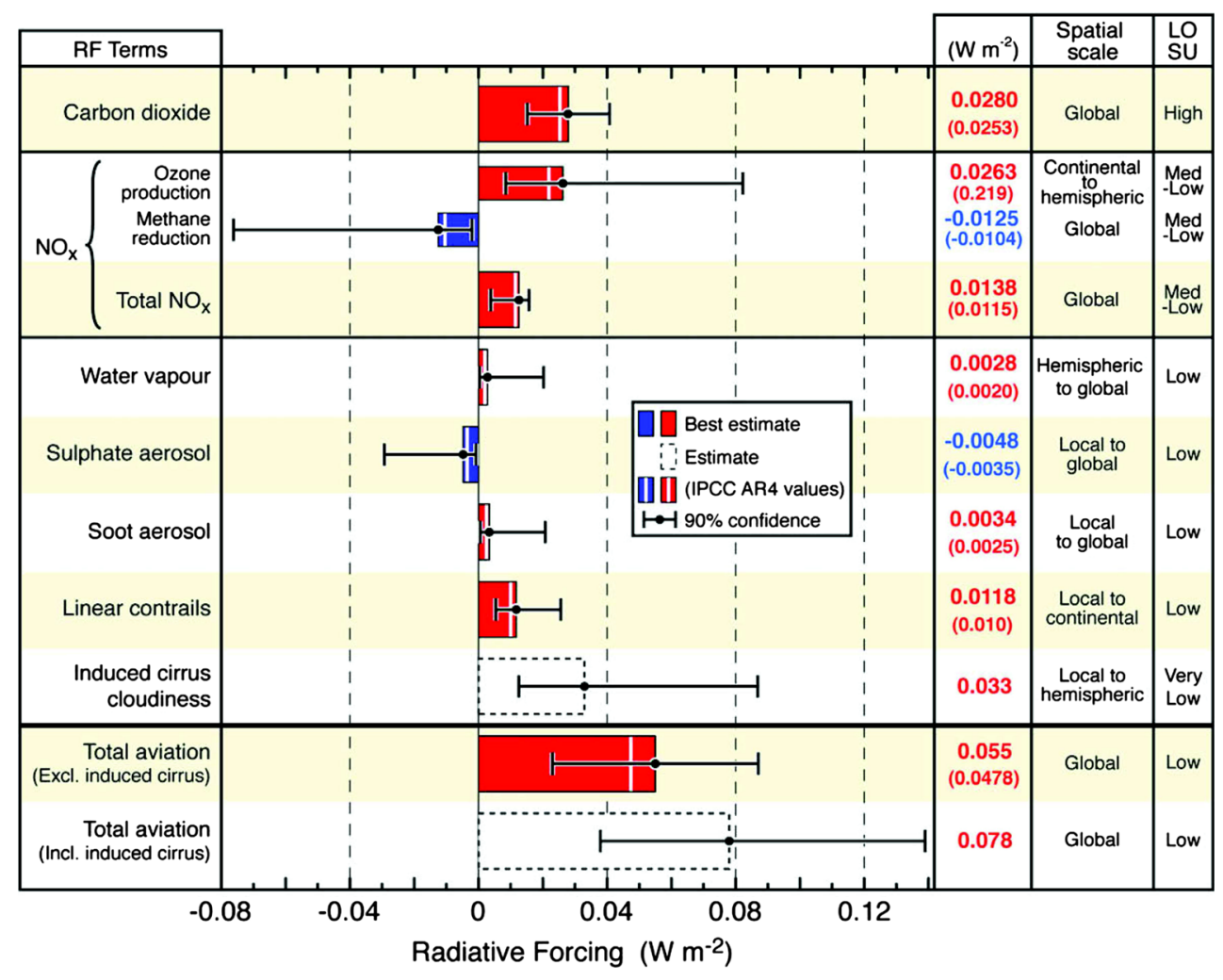

- Cirrus formation, from contrails.

2. Cooling effects:

- $\mathrm{CH}_{4}$ concentration reduced, due to $\mathrm{NO}_{x}$,

- Sun light reduced, due to sulfur aerosols.

3. Direction of effects unclear:

- Modification of present cirrus cloudiness.

\subsection{Effects of aromatics and particles}

In general, aromatics including polyaromatic hydrocarbons (PAH) are among the most widespread organic pollutants in the environment due to incomplete combustion of organic material, also from forest fires. A specific PAH can be of significant health adverse effects, ranging from toxic, 
to carcinogenic, and mutagenic. In addition, aromatics are major precursors of soot particles with potentially severe health effects, in particular, the so-called ultrafine particles, less than $100 \mathrm{~nm}$ in diameter [46]. In the past, PAH emissions from aircrafts have been considered to be low, with no need for actions to be taken.

Particulate emissions are in the focus when considering the potential of aircrafts emissions on improving airport air quality and when looking at effects of aircrafts emissions on contrails. The main reason is that particles (soot or sulfur containing species) serve as nucleation centers for ice crystal formation. Thus, they may affect the growth and lifetime of contrails, depending on several atmospheric parameters, such as pressure, temperature, turbulence level, and relative humidity. Especially contrails are known to be of relevance for the climate due to their radiative forcing [42]; however, only when persistent [45].

Contrail formation is a thermodynamically controlled process. Contrails are formed when the exhaust gas achieves transiently a supersaturated state while mixed with ambient air, as expressed by the Schmidt-Appleman criterion [47]. This will initiate condensation of water which subsequently freezes. The Schmidt-Appleman criterion is valid for all types of fuels. In addition to atmospheric parameters, contrail formation depends on aircraft parameters (overall propulsion efficiency) and fuel parameters (the energy specific emission index (EI) of water vapor, $\mathrm{EI}_{\mathrm{H} 2 \mathrm{O}} / Q$; that is, the ratio between the emission index of water vapor, $\mathrm{EI}_{\mathrm{H} 2 \mathrm{O}}$, and the lower calorific value of the fuel, $Q$ ).

Serving as a nucleus, particles may affect the dominance of freshly formed ice crystals, in number, mass, and size [48]. Thus, contrails properties may differ if particulate emissions of alternative jet fuels differ compared to those of Jet A-1.

\section{Composition of aviation fuels}

The combustion of any fuel, as well as the emissions are linked to the specific composition of the fuel and to the combustion determining parameters, such as temperature, pressure, and fuel-air ratio. Therefore, it is necessary to look at the specific composition of the synthetic kerosenes and at the major differences to Jet A-1/A from crude-oil. The aim of the present work is to elaborate the interaction between the composition of a jet fuel and its molecular properties-thermo-chemical and thermo-physical.

\subsection{Jet A-1}

A typical kerosene from crude oil (Jet A-1) consists of a large variety of different species belonging to four chemical families: (1) long-chained unbranched alkanes ( $n$ -

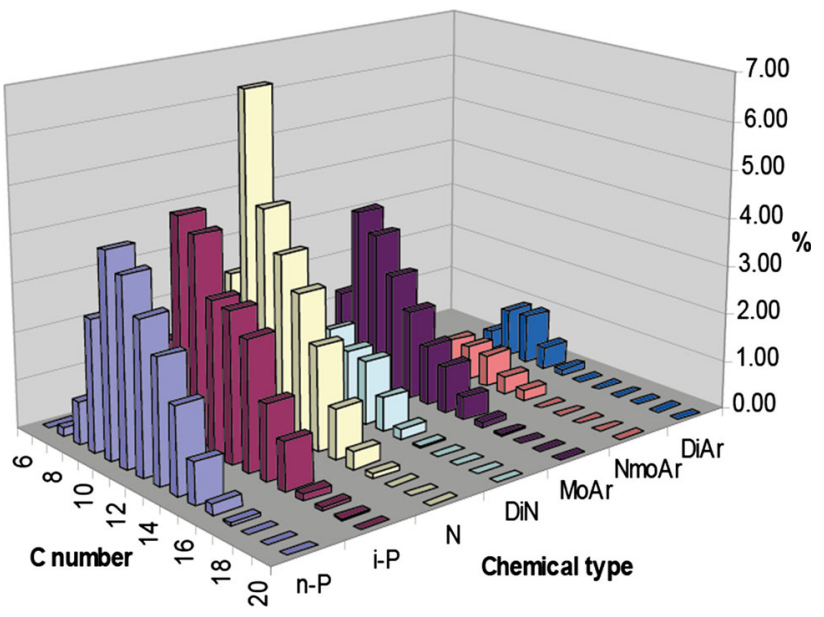

Fig. 5 Chemical composition of a Jet A-1 [49]

alkanes or $n$-paraffins), (2) long-chained, branched alkanes (iso-alkanes or iso-paraffins), (3) cyclo-alkanes (naphthenes or cyclo-paraffins), and (4) aromatics. A detailed knowledge about the amount and type of chemical components can be obtained by applying a GC/MS or a GC/ GC/MS analysis, as shown in Fig. 5. Sulfur can be present, but must be less than 3000 ppm, besides fuel additives such as antioxidants, antistatic agents, and metal deactivators.

\subsection{Current alternative jet fuels}

Currently five types of alternative jet fuels are certified and approved; for an overview, see [12-14]. From fossil feedstocks, CtL (Coal to Liquid) and GtL (Gas to liquid, natural gas) are produced. Today, with SIP (synthesized iso-paraffins) formally referred to DSHC (direct sugar to hydrocarbon), HEFA (hydro processed esters and fatty acids), BtL (biomass to liquid), and alcohol to jet (ATJ) four conversion technologies are available for the production of sustainable alternative fuels, providing substantial progress regarding sustainability and $\mathrm{CO}_{2}$ emissions.

Further jet fuel candidates, such as catalytic hydrothermolysis $(\mathrm{CH})$, with the potential to be used as a drop-infuel without the need of blending with conventional fuels, and hydroprocessed depolymerized cellulosic jet (HDCJ) are discussed and investigated; they are currently under review by ASTM.

Today, the technical feasibility of alternative jet fuels has been proven [12-29]. Many commercial flights with biofuels have taken place so far. Due to the certification, alternative jet fuels are assumed to perform appropriate with respect to the combustion in the aero engine and to the whole fueling system including material aspects (sealing) and thermo stability aspects of the fuel itself. However, as emissions depend on the type of aero engine, emission tests are not part of the approval protocol. 


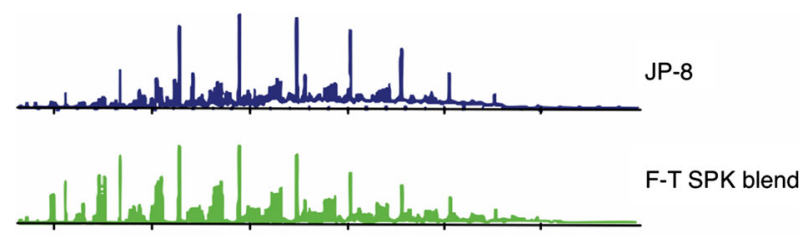

HEFA SPK blend

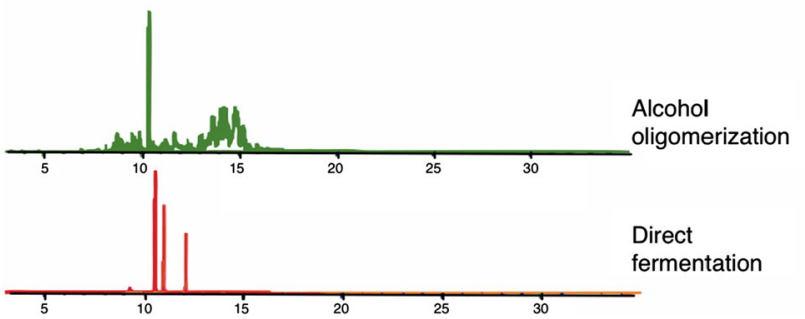

Fig. 6 Gas chromatograms of approved jet fuels and near-future candidates [8]

The composition of synthetic jet fuels is similar to the one of Jet A-1 in that sense that they are also composed of hydrocarbons only. However, the amount and length of hydrocarbons, as well as the number of chemical families and the H/C ratio might differ considerably (Fig. 6).

Synthetic aviation fuels available today can be considered as synthetic paraffinic kerosenes (SPK): they are practically free from aromatics and sulfur; in addition, they contain no fuel-bound nitrogen. Thus, they are promising an emission pattern with a reduced detrimental factor on the environment.

For example a GtL fuel is a mixture of only three chemical families, without any aromatics (Fig. 7). This affects the emission behavior leading to a considerably reduced number of particulates; i.e., having a better performance with respect to, e.g., the local air quality when compared to crude-oil kerosene [13].

\section{Measurements of emissions from alternative jet fuels}

The synthetic jet fuels certified and approved show a different composition when compared to crude-oil kerosene. Hence, the emission characteristics might also differ when burning these fuels in a jet engine.

In the last years, several experimental investigations have been performed focusing on the emissions pattern of jet engines operated with alternative jet fuels, mostly SPKfuels (GtL, BtL, CtL), and HEFA. Quite recently, farnesane (SIP-fuel)-2,6,10 trimethyldecane $\mathrm{C}_{15} \mathrm{H}_{32}$, the latest approved alternative fuel component-was studied.

Studies on the emission pattern in exhaust plumes are limited. An overview of major relevant studies is given in (a)

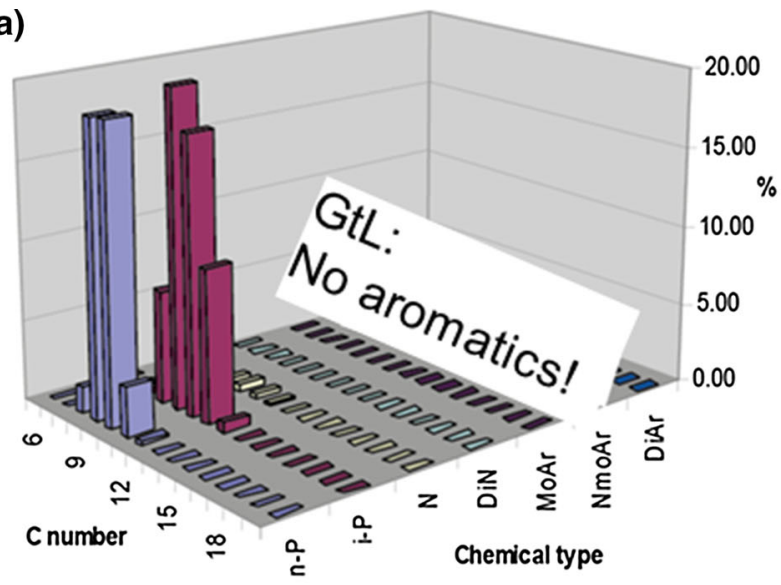

(b)

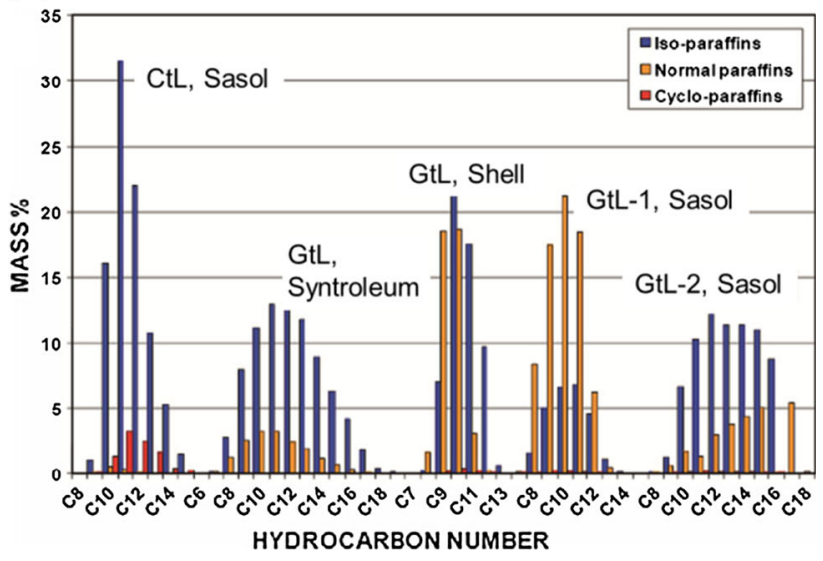

Fig. 7 Chemical compositions of several different GtL fuels: a [49]; b [28]

Table 3. The fuels were studied both neat and in blends with petroleum-derived fuels [12, 22-24, 28, 50-71], as a response to the approval protocol; see also [72].

In the studies, the emissions measured include gaseous emissions, mostly $\mathrm{CO}, \mathrm{CO}_{2}, \mathrm{NO}_{x}, \mathrm{UHC}$, and particle emissions (mass, number, and size), besides sulfur containing species, aromatics, and aldehydes [66]. For comparison, the emission pattern of crude-oil kerosene was measured also. In addition, further parameters such as humidity and temperature, as well as physical properties such as viscosity or sauter mean diameter were also part of the studies [70], but not in all of them. Similar, thrust, as well as combustor pressure was varied, to get further insights into the effect on emissions.

The measurements by Wahl et al. [22, 62-65] were done using the following instruments: (1) a TSI-EEPS model 3090 for measuring particle size distribution in diluted exhaust; (2) a Dekati-DiluterDI-1000 for diluting; and (3) a MKS Multi Gas 2030 FTIR continuous gas analyzer for $\mathrm{CO}, \mathrm{CO}_{2}$, and $\mathrm{NO}_{x}$ (gaseous undiluted). For sampling, neither a thermo denuder nor a catalytic stripper was used. Instead, a stainless steel sampling line, $25 \mathrm{~m}$ in length, with 
Table 3 Overview of relevant studies on emissions of alternative fuels

\begin{tabular}{|c|c|c|c|c|}
\hline Project & Fuels tested & Type & Parameter & References \\
\hline \multicolumn{5}{|c|}{ I: Aircraft studies—flight campaigns and ground-based } \\
\hline burn-FAIR & Jet A-1 & Engine test bed & $\mathrm{CO}, \mathrm{CO}_{2}$ & {$[22]$} \\
\hline Flight campaign & HEFA & Ground & $\begin{array}{l}\mathrm{NO}_{x}, \mathrm{SO}_{2}, \\
\mathrm{CH}_{4} \\
\text { Particles: } \\
\text { mass, size number }\end{array}$ & \\
\hline ECLIF & Jet A-1 & Ground and flight & Gaseous emissions & {$[55]$} \\
\hline Flight campaign & Several alternative fuels & level & Particles & \\
\hline ACCESS & $\begin{array}{l}\text { Base JP-8 } \\
\text { 1:1 HEFA blend }\end{array}$ & Engine & $\begin{array}{l}\text { Gases, } \\
\text { particles }\end{array}$ & {$[52]$} \\
\hline AAFEX I & Neat: & Engine & $\mathrm{CO}, \mathrm{CO}_{2}$ & {$[51-53]$} \\
\hline Ground-based & $\begin{array}{l}\text { JP-8 } \\
\text { CtL, GtL } \\
50 / 50 \text { blends of } \\
\text { CtL/JP-8 } \\
\text { GtL/JP-8 }\end{array}$ & APU & $\begin{array}{l}\mathrm{NO}_{x}, \mathrm{SO}_{2}, \\
\mathrm{CH}_{4}, \\
\text { Particles: } \\
\text { mass, size number }\end{array}$ & \\
\hline AAFEX II & Neat: & Engine & $\mathrm{CO}, \mathrm{CO}_{2}$ & {$[50]$} \\
\hline Ground-based & $\begin{array}{l}\text { JP-8 } \\
\text { CtL, GtL } \\
50 / 50 \text { blends of } \\
\text { CtL/JP-8 } \\
\text { GtL/JP-8 }\end{array}$ & APU & $\begin{array}{l}\mathrm{NO}_{x}, \mathrm{SO}_{2}, \\
\mathrm{CH}_{4}, \\
\text { Particles: } \\
\text { mass, size number }\end{array}$ & \\
\hline \multicolumn{5}{|c|}{ II: EU funded projects } \\
\hline Alfa-BIRD & $\begin{array}{l}\text { GtL-SPK } \\
\text { GtL }+20 \% \text { hexanol } \\
\text { GtL }+50 \% \text { naphthenic cut } \\
\text { CtL-FSJF }\end{array}$ & Engine test bed & $\begin{array}{l}\mathrm{CO}, \mathrm{CO}_{2}, \\
\mathrm{NO}_{x}, \mathrm{CH}_{4}, \\
\text { Particles: } \\
\text { mass, size number }\end{array}$ & [23] \\
\hline SWAFEA & $\begin{array}{l}\text { Jet A-1; GtL } \\
\text { HEFA/Jet A-1 } \\
1: 1 \text { and } 3: 1 \\
\text { FAE/Jet A-1 } \\
1: 9\end{array}$ & Engine test bed & $\begin{array}{l}\text { Gaseous emissions } \\
\text { Particles }\end{array}$ & {$[24]$} \\
\hline HBBA & $\begin{array}{l}\text { CtL, HVO, } \\
\text { AtJ-SPK } \\
\text { AtJ-SKA } \\
\text { farnesane } \\
\text { CH-kerosene }\end{array}$ & Engine test bed & $\begin{array}{l}\mathrm{CO}, \mathrm{CO}_{2}, \\
\mathrm{NO}_{x}, \mathrm{SO}_{2}, \\
\mathrm{CH}_{4}, \\
\text { Particles: mass, size number }\end{array}$ & {$[56]$} \\
\hline \multicolumn{5}{|c|}{ III: Academia and research } \\
\hline $\begin{array}{l}\text { DeWitt } \\
\text { et al. }\end{array}$ & $\begin{array}{l}\text { GtL, CtL, HEFA } \\
\text { aromatics } \\
\text { Jet A-1 }\end{array}$ & $\begin{array}{l}\text { T63 engine } \\
\text { APU }\end{array}$ & $\begin{array}{l}\text { Gaseous emissions } \\
\text { Particles }\end{array}$ & {$[57-59]$} \\
\hline $\begin{array}{l}\text { Lobo et al. } \\
\text { Thomson et al. }\end{array}$ & $\begin{array}{l}\text { Biomass fuels, FT-fuels, Jet A } \\
\text { Alfa-BIRD fuels }\end{array}$ & $\begin{array}{l}\text { CFM56-7B eng. } \\
\text { Burner } \\
\text { Diffusion }\end{array}$ & $\begin{array}{l}\text { Particulate } \\
\text { Soot volume fraction }\end{array}$ & $\begin{array}{l}{[54]} \\
{[60,61]}\end{array}$ \\
\hline Wahl et al. & $\begin{array}{l}\text { GtL: } \\
2 \text { Jet A-1 fuels, with a share of: } \\
\text { 10, } 20,30,50 \% \text { GtL; } \\
\text { Fanesane: } \\
\text { Jet A-1, with a share of: } 0,10 \text {, and } \\
20 \% \text { farnesane }\end{array}$ & $\begin{array}{l}\text { P\&W Canad.JT15D-4 } \\
\text { Engine } \\
\text { Test bed } \\
\text { CFM56-5C4 }\end{array}$ & $\begin{array}{l}\text { Gaseous emissions } \\
\text { Particle-mass, number }\end{array}$ & {$[62-65]$} \\
\hline
\end{tabular}


Table 3 continued

\begin{tabular}{|c|c|c|c|c|}
\hline Project & Fuels tested & Type & Parameter & References \\
\hline Wilson et al. & $\begin{array}{l}\text { Alfa-BIRD fuels, SWAFEA- } \\
\text { fuels: }\end{array}$ & Engine test bed & $\begin{array}{l}\mathrm{CO}, \mathrm{NO}_{x} \\
\text { UHC } \\
\text { Particles }\end{array}$ & {$[12,66-69]$} \\
\hline Zarzalis et al. & Alfa-BIRD fuels & Engine test bed & $\begin{array}{l}\mathrm{CO}, \mathrm{CO}_{2} \\
\mathrm{NO}_{x}, \mathrm{UHC} \\
\text { Particles }\end{array}$ & {$[70]$} \\
\hline
\end{tabular}

FAE fatty acid ester

Table 4 Selected fuel properties of the farnesane/ JetA-1 blends by Wahl et al. [62]

\begin{tabular}{|c|c|c|c|}
\hline \multirow[t]{2}{*}{ Property } & \multicolumn{3}{|l|}{ Fuel } \\
\hline & Jet A-1 & Jet A-1 $+10 \%$ farnesane & Jet A-1 $+20 \%$ farnesane \\
\hline Density $/ \mathrm{kg} \mathrm{m}^{-3}$ & 793.2 & 791.5 & 789.4 \\
\hline Smoke point/mm & 25 & 25 & 26 \\
\hline Aromatics/vol \% & 16.6 & 15.1 & 14.1 \\
\hline Heat of combustion/MJ kg & 43,295 & 43,376 & 43,444 \\
\hline
\end{tabular}

an internal diameter of $6 \mathrm{~mm}$, was used followed by a Dekati-DiluterDI-1000. The line was heated electrically to $T=433 \mathrm{~K}$, with no line loss corrections done as the focus was set on comparison measurements, under the same conditions. By assuming a soot density of $1 \mathrm{~g} \mathrm{~cm}^{-3}$ [73], the volume distributions were converted to soot mass. Surface, number, and geometric mean diameter were determined based on mobility analysis assuming spherical particles.

Measurements on farnesane are reported for the first time $[56,62]$. Selected fuel properties of these mixtures are given in Table 4 as reported in [62]. The $\mathrm{H} / \mathrm{C}$ ratio was not determined. The $\mathrm{H} / \mathrm{C}$ ratio of farnesane, $\mathrm{C}_{15} \mathrm{H}_{32}$, is 2.13 , and 1.92 for Jet $\mathrm{A}-1$, with $\mathrm{C}_{12} \mathrm{H}_{23}$. Thus, the $\mathrm{H} / \mathrm{C}$ ratio will increase slightly for Jet A-1/farnesane blends.

In summary, the studies have shown that the emission pattern of alternative aviation fuels show a different picture than the one of Jet A-1: Major gaseous emissions (CO, $\mathrm{CO}_{2}$, and $\mathrm{UHC}$ ) were reduced slightly, depending also on thrust; considering $\mathrm{NO}_{x}$, no clear trend was reported, although mostly reported to be reduced; particulate matter (PM) emissions were significantly reduced (both in mass and particle number).

\subsection{CO emissions}

The expected trends were observed: $\mathrm{CO}$ emissions are highest at low power settings (idle, taxi). In general, a slight reduction in $\mathrm{CO}$ is found for most of the alternative fuels studied. This was reported for GtL and $\mathrm{CtL}$ compared to JP-8 [52] with $\mathrm{CO}$ emissions from GtL lower by about $10 \%$ in idle and take-off. From wing ground engine tests,
Wahl et al. observed at idle power settings a minor improvement in CO with increasing GtL content [63], with no GtL effect at higher power settings.

In addition, the amount of $\mathrm{CO}$ emissions depends on the test method, as expected, too. According to Wilson et al. [12], CO emissions for alternative fuels were ranging from a $20 \%$ reduction over the LTO-cycle for a P\&W 4 burner sector rig burning a fully synthetic Fischer-Tropsch (FT) fuel, to an $8 \%$ increase from a CFM56-7B engine test burning blends of HRJ (hydrotreated renewable jet fuel).

Furthermore, DeWitt et al. demonstrated that the $\mathrm{CO}$ emission is significantly dependent on fuel aromatic content [59]. The T63 engine was tested on JP-8 and two GtL fuels with a range of aromatic solvents added. A reduction of $\mathrm{CO}$ emissions by $22 \%$ was observed at idle; addition of three different aromatic compounds, at $20 \%$ concentration, leads to higher CO levels, ranging between 9 and $32 \%$, with the heavier aromatics having the largest effect on $\mathrm{CO}$ [59]. This finding was explained by a reduction in combustion efficiency due to an increase in aromatics and molecular weight.

Only a slight reduction of $\mathrm{CO}$ emissions were noticed by Wilson et al. [67] in testing the SWAFEA-fuels, mostly Jet A-1 blends of FAE and HEFA.

Testing the Alfa-BIRD fuels, Zarzalis et al. [70] measured higher $\mathrm{CO}$ levels with an increase in equivalence ratio attributed to the acceleration of the dissociation process of $\mathrm{CO}_{2}$ to $\mathrm{CO}$. They noticed that the naphthenic blend emits the highest levels of CO, with FSJF emits the lowest $\mathrm{CO}$ emissions. Blending of either naphthenic cut or hexanol in FT-SPK increases the CO formation compared with 


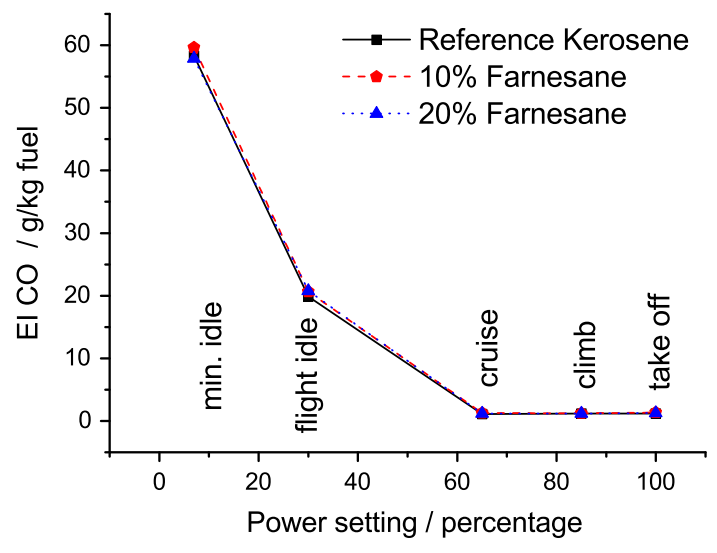

Fig. $8 \mathrm{CO}$ emissions of two farnesane/Jet A-1 blends and reference kerosene (Jet A-1) [56, 62]

neat FT-SPK. The authors pointed out that $\mathrm{CO}$ emissions are sensitive to effects caused by the fuel injector used resulting in differences in the homogeneity levels in the combustor.

Moses [28] also reported a lower CO formation of a CtL (FSJF) compared to Jet A-1. This was referred to the lower viscosity of the alternative fuel compared to Jet A-1 resulting in a better atomization and consequently lower CO formation.

When studying farnesane in a CFM56-5C4 engine no discernible effect on $\mathrm{CO}$ emissions were measured by Wahl et al. [56, 62]. CO emissions are basically identical for the two farnesane/kerosene blends studied and for kerosene as reference (Fig. 8).

\section{$4.2 \mathrm{CO}_{2}$ emissions}

The $\mathrm{CO}_{2}$ emissions are observed to increase with increasing engine power, as expected. This is coming along with a concurrent decrease in $\mathrm{CO}$ emissions. The reasons for these findings are improved combustion efficiency at higher power settings.

It is mostly noticed that the $\mathrm{CO}_{2}$ formation behavior of the investigated synthetic aviation fuels blended in Jet A-1 are almost identical.

Wilson et al. reported on the dependency of the $\mathrm{CO}_{2}$ level with the caloric value of the fuel [12]. Synthetic fuels have a slightly higher calorific value compared to Jet A-1 $[13,23,24]$. Although these differences are quite low, usually between 1 and $2 \%$, significant lower $\mathrm{CO}_{2}$ emissions are resulting. This was shown also on engine demonstration flights; see, e.g., [22, 72].

Wahl et al. reported on $\mathrm{CO}_{2}$ concentration measurements $[56,62]$ when studying the combustion of farnesane addition to Jet A-1. The findings verify the reproducibility of engine power settings and probe sampling (Fig. 9) during the tests.

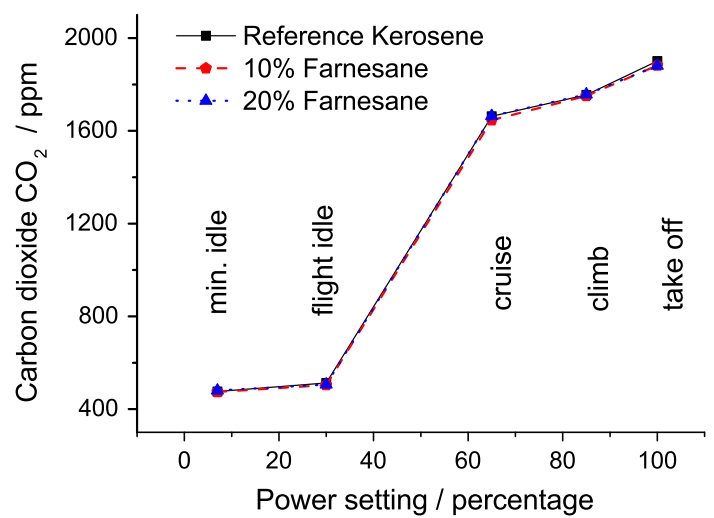

Fig. $9 \mathrm{CO}_{2}$ emissions of two farnesane/Jet A-1 blends and reference kerosene (Jet A-1) [56, 62]. 429.9 ppm $\mathrm{CO}_{2}$ background subtracted

\section{3 $\mathrm{NO}_{x}$ emissions}

Concentrations of $\mathrm{NO}_{x}$ emissions are strongly dependent on combustion parameters, in particular, temperature and residence time. The dominant $\mathrm{NO}_{x}$ formation pathway is thermal- $\mathrm{NO}_{x}$, also referred to Zeldovich $\mathrm{NO}_{x}$, according to the following three reactions:

$$
\begin{aligned}
& \mathrm{O}+\mathrm{N}_{2}=\mathrm{NO}+\mathrm{N}, \\
& \mathrm{N}+\mathrm{O}_{2}=\mathrm{NO}+\mathrm{O}, \\
& \mathrm{N}+\mathrm{OH}=\mathrm{NO}+\mathrm{H} .
\end{aligned}
$$

Due to the high activation energy, the thermal- $\mathrm{NO}_{x}$ pathway is opening at high temperatures, $T>1800 \mathrm{~K}$, and becomes dominant at even higher temperatures. Hence, the concentrations of $\mathrm{NO}_{x}$ emissions follow the adiabatic flame temperature of the air-fuel mixture as shown by modeling calculations [72].

In addition, it is important to have accurate knowledge on ambient humidity and temperature when evaluating the differences in $\mathrm{NO}_{x}$ emissions between different fuels $[12,70,72]$.

Overall, a reduction of $\mathrm{NO}_{x}$ emissions resulting from synthesized aviation fuels was observed. For example, Wilson et al. [12] reported on a reduction by up to $12 \%$, for a FT- or a HEFA-fuel, as well as for fatty acid methyl esters (FAME). A reduction in $\mathrm{NO}_{x}$ levels was also found in the AAFEX test campaigns, in particular, at high power settings, for CtL and GtL fuels [50-53].

This finding was also reported by Wahl et al. [63, 64] for mixtures with GtL as alternative aviation fuels. However, the effect was dependent on the type of Jet A-1 used for reference.

With respect to the two farnesane blends (Fig. 10), a slight reduction of $\mathrm{NO}_{x}$ concentrations was observed for most power settings. However, the effect is weak and not completely consistent (cruise) [56, 62].

For the Alfa-BIRD fuels, differences in the $\mathrm{NO}_{x}$ formation behavior were measured, with $\mathrm{CtL}$ having lower 


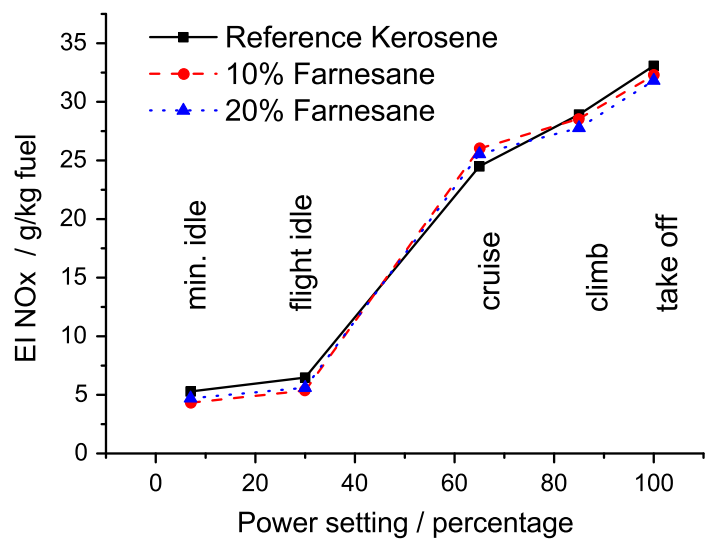

Fig. $10 \mathrm{NO}_{x}$ emissions of two farnesane/Jet A-1 blends and reference kerosene (Jet A-1) [56, 62]

values than Jet $\mathrm{A}-1$, and GtL having the highest values, respectively [70]. This behavior was attributed to their different degrees of mixing with air in the combustor. By taking this effect into account, the tendency was shown to correlate well with their different measured combustor temperatures, with GtL shown the highest temperature.

\subsection{Aromatics, particles, and soot}

A detailed information on the sooting characteristics of alternative aviation fuels is needed for a number of reasons: (1) Radiation by soot particles is the major mechanism how heat is transferred to the combustor walls in a gas turbine engine; (2) effects on local air quality; (3) twofold effects on Radiative Forcing, as soot has a major impact on contrails properties as well as on cirrus cloud formation.

Overall, the measurements performed show a reduction in soot emissions, mostly attributed to the lack of aromatics. Thus, these findings confirm the effects of a fuel's chemical composition on its emissions; i.e., of aromatics on emissions of soot.

Wilson et al. reported on smoke measurements of the SWAFEA synthetic fuels performed in an Auxiliary Power Unit (APU) [12, 24]. Jet A-1 has the highest smoke number, followed by $\mathrm{CtL}$ (high aromatic content), and GtL with a very low level of smoke emissions reflecting the share of aromatics within the fuels studied.

Within the NASA APEX, AAFEX, and ACCESS missions, the impact of jet fuel properties on aerosols emitted by CFM56-2-C1 engines burning 15 different aviation fuels was investigated, with HEFAs and two fossil derived FT-fuels, GtL and CtL, representing synthesized certified aviation fuels [50-53]. From the ground tests measurements it was found that the fuel aromatic content, as well as sulfur, has a direct impact on soot emissions for all engine power ranges. The naphthenic content of the fuel determines the magnitude of the soot number and the soot mass.
It is reported that reducing both fuel sulfur content and naphthenes to near-zero levels would result in roughly a 10 -fold decrease in aerosol number [50-53].

In detail, particle emissions from $\mathrm{GtL}$ and $\mathrm{CtL}$ fuels are substantially lower compared to those of JP-8; e.g., for GtL neat, by about a factor of 20 at low and medium power ranges. Reductions were also observed for GtL/JP-8 blends; however, not proportional. In addition, no soot emissions were measured when using a HRJ fuel.

Soot volume fractions of the alternative fuels considered in the Alfa-BIRD project have been measured by Thomson et al. [60] in a laminar diffusion flame at atmospheric pressure. A clear ranking of the fuels with respect to soot concentrations and sooting indices was observed, with the highest values for Jet $\mathrm{A}-1$, and lower values for $\mathrm{CtL}$, $\mathrm{GtL}+$ naphthenic cut, GtL, and GtL+hexanol. Moreover, it was shown that the soot concentrations, as well as the threshold soot indices (TSI) values are strongly dependent on the aromatic content of the fuels. In detail, the soot levels in flames were reported to be proportional to benzene concentrations, but not to acetylene levels.

Within burn-FAIR, Wahl et al. [22] performed engine ground tests at Lufthansa Technik test facility to evaluate the impact of alternative fuel blends (HVO) on a V2500 engine, in service on an Airbus A 321. Practically no reduced soot emissions were observed. This observation might be explained by the following two points [22]: (1) The alternative fuel blend (HVO+Jet A-1) provided by the fuel distributor used a different Jet A-1 than the Jet A-1 fuel used as reference in the commercial flights because blending an alternative fuel at the airport is not allowed. In addition, it is known that the composition of a Jet A-1 can differ considerably over the year including the amount of aromatics. (2) Overmore, the relative amount of components with a lower and higher boiling point, respectively, may also affect the amount of soot emissions, resulting in lower or in higher levels, respectively. This assumption was confirmed by the evaluation of the measured GC/MS spectra of the reference Jet A-1 and of the (HVO+Jet A-1) blend: the last one depicts species of a lower and of a higher boiling point in addition to those identified in Jet A-1 (reference).

Engine ground tests with three GtL/Jet A-1 mixtures, with a GtL percentage $(0,10$, and $50 \%)$ were performed by Wahl et al. [63, 64] on a Cessna Citation II powered with Pratt and Whitney turbofan engines (P\&W Canada JT15D4). They reported that at the power settings used (ICAO LTO-cycle) the emission indices for particles (mass and number) are significantly reduced by increasing the GtL percentage. Particle diameters were also reduced by increasing the $\mathrm{GtL}$ content.

With respect to the work of adding farnesane to Jet A-1 tested in a CFM56-5C4 engine $[56,62]$ a clear reduction is 
seen in the soot particle emissions. This is attributed to the chemical structure of farnesane, being a long-chained isoalkane, with no aromatic structure.

Increasing percentage of farnesane in Jet A-1 results in a corresponding reduction in particle emissions. Concerning particle mass, there is a clear reduction at all test points by increasing farnesane content. Furthermore, a reduction of soot surface was measured at all power settings, with a quite clear reduction at high power settings (Fig. 11). The highest relative reduction was observed at the low power settings "min. idle (taxi)" and "flight idle (approach)". The number of soot particles has been also reduced, by about 10-20\%; however, no consistent effect was found on the soot's mean diameter (Fig. 12). Although the reductions in mass and number would expect a reduction in the size of the particle also, obviously, larger particles are observed when adding farnesane to Jet A-1. Note that comparison measurements have been conducted, under the same conditions, as pointed out above. This point underlines the need of further investigations on emissions from alternative jet fuels. However, this finding is of relevance with respect to the adverse health effects of ultrafine particles [46].
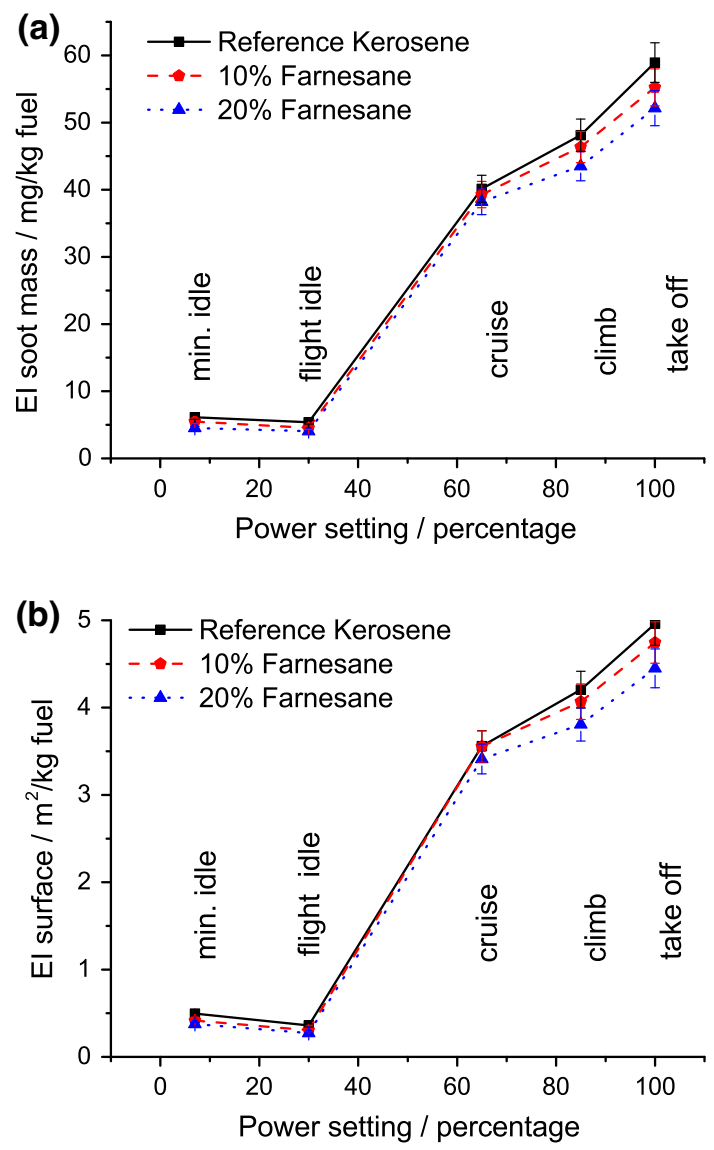

Fig. 11 Soot emissions of two farnesane/Jet A-1 blends and reference kerosene (Jet A-1) [56, 62]: a Soot mass; b soot surface
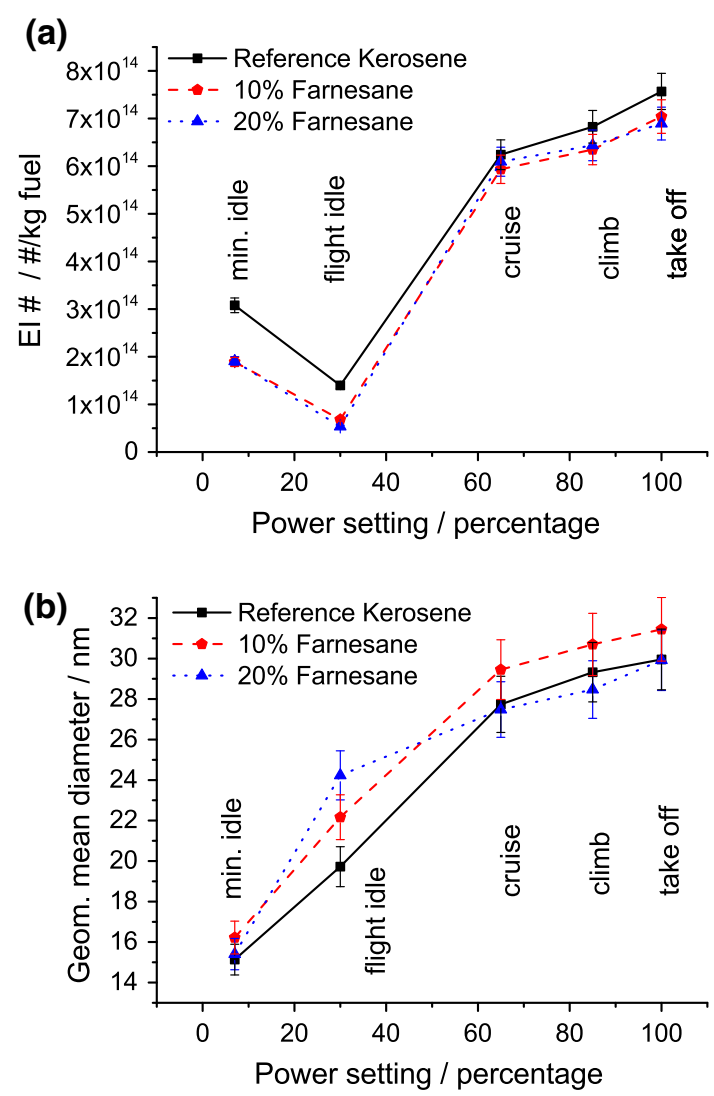

Fig. 12 Soot emissions of two farnesane/Jet A-1 blends and reference kerosene (Jet A-1) [56, 62]: a EI particles; b geometric mean diameter of particles

The differences observed in particle number and mass are statistically significant because each was measured at a stable engine power setting for $3 \mathrm{~min}$ with a time resolution of $10 \mathrm{~Hz}$ (EEPS) leading to 1800 spectra. Thus, the experimental uncertainty in the measurements is estimated to be about $\pm 5 \%$. Furthermore, the farnesane blends perform similar to or better than the reference kerosene. For example, total mass and total surface of particles are reduced by up to about 25\% (idle) and 5\% (cruise), respectively. Number of particles is reduced by up to about $40 \%$ (idle) and $7 \%$ (cruise), respectively. These reductions can help to improve airport air quality and may have an impact on future airport ground operations issues.

\section{Summary and conclusions}

The composition of alternative aviation jet fuels is known to differ considerably, with respect to each other and to Jet A-1, in terms of amount and type of hydrocarbons. Compared to crude-oil kerosene, certified alternative aviation fuels are almost aromatics and sulfur free. However, comprehensive emissions studies are not part of the approval process. Emissions of jet fuels are a mixture of 
gaseous and non-gaseous species released at ground level (airport, local air quality) and at flight level (climate).

In the present paper, an overview of investigations of the emissions characteristics of synthesized jet fuels was given. Most of the experiments were performed at test rigs; relevant data gathered from measurements of experiments at flight levels are scarce.

Mostly, the same general trends were reported for the emissions of interest, for the fuels considered, and at the power settings selected, with no adverse emissions effects. The main findings are the following:

- Emissions of $\mathrm{CO}, \mathrm{CO}_{2}$, and $\mathrm{NO}_{x}$ are mostly unaffected or reduced;

- A clear improvement is observed for soot particle emissions, in mass and in number density, in particular for GtL, HEFA, and farnesane;

- A strong link between the amount and type of aromatics content of a jet fuel and soot emissions was observed.

Fuel composition can be used to estimate the reduction in emissions insofar that, in general, the lower the amounts of aromatics, the lower the amounts of soot $[14,72,74]$. In addition, with increasing $\mathrm{H} / \mathrm{C}$ ratio, fewer amounts of particles are expected. Exemplarily, the farnesane blends experiments are supporting these issues.

However, the experimental data reported cannot always be interpreted unambiguously. For example, when conducting engine tests or burner experiments, it is a wellknown fact that measurements performed with air-blast atomizers are relatively more sensitive to the properties of the liquid fuel compared to commonly used pressure atomizers. Thus, any small differences in fuel properties may lead to significant differences in their atomization characteristics [70]. A better atomization implies a more homogenous mixture, leading to a more complete combustion and a higher temperature; both are affecting the fuel's emissions.

In addition, it is important to have an accurate knowledge on ambient humidity and temperature when evaluating differences in the emissions between alternative fuels and crude-oil kerosene [12]. Furthermore, as blends of alternative fuels in conventional kerosene are often studied, as a response to their approval, it is of utmost importance to have a comprehensive knowledge of the properties of the reference fuel itself. Otherwise, a correct interpretation of the obtained data will not be straightforward or even impossible.

The strong connection between aromatics and soot emissions needs to be studied further. First, soot emissions are known to affect earth's Radiative Forcing constant. Furthermore, they may play an important role on contrail properties and on cirrus cloud formation. However, the present data from emissions at flight level is too limited to allow a comprehensive evaluation of the effects of soot emission on global warming when switching from crudeoil kerosene to alternative aviation fuels. Second, focusing on improving local air quality, the benefit from using alternative aviation fuels appears straightforward, as reduced soot emissions are observed, in particular at idlelow and taxi. The mean diameter of soot particles emitted needs to be measured also because of the relevance of ultrafine soot particles on health.

In particular, models are needed that are able to address appropriately thermo-physical properties of the liquid fuels, e.g., surface tension, viscosity, Sauter Mean Diameter, which is relevant for the fuel break-up. The combustion in a jet engine must be investigated by a comprehensive model that is able to describe correctly all relevant sub-processes, fuel-break-up, combustion properties, heat release, ignition, and blow-out under turbulent conditions, at high temperature and pressures.

For validation of the models, first relevant lab-scale experiments need to be performed, systematically, for the fuels and parameter range of interest, covering physical and chemical properties. Reaction models, detailed and reduced, are needed which describe the combustion of aviation fuels. A systematic investigation of the effect of aromatics is also needed.

Then, emission pattern of alternative fuels needs to be determined under well-defined conditions, from engine ground tests and within flight campaigns.

Furthermore, lab-scale experiments will guide flight campaigns testing alternative fuels emissions. Presently, such data are scarcely available, mostly due to the high costs and complicated logistics.

In summary, a comprehensive knowledge of synthetic jet fuel properties is needed, preferably by a combined effort of computational fluid dynamics modeling and experimental characterization. Thus, a more efficient and optimized use of synthetic fuels in aero-engines can be achieved.

Acknowledgements The financial support of the European Commission within the tender "Condensation trails from biofuels/kerosene blends scoping study", ENER/C2/2013-627, is gratefully acknowledged. The authors thank A. Zschocke for sharing the experimental results on emissions of farnesane-kerosene mixtures, K.P. Gierens for fruitful discussions, and M. Kapernaum and M. Dietrich for assistance.

\section{References}

1. Kohse-Höinghaus, K., Oßwald, P., Cool, T.A., Kasper, T., Hansen, N., Qi, F., Westbrook, C.K., Westmoreland, P.R.: Biofuel combustion chemistry: from ethanol to biodiesel. Angew. Chem. Int. Ed. 49, 3572-3597 (2010)

2. Intergovernmental Panel on Climate Change IPCC.: Mitigation of climate change. Contribution of Working Group III to the Fifth 
Assessment Report of the IPCC. In: Edenhofer, O., et al. (eds.), Cambridge University Press, Cambridge, United Kingdom and New York, NY, USA (IPPC) (2014), http://www.ipcc.ch/report/ ar5/wg3/. Accessed 26 Aug 2015

3. Steil, U., Braun-Unkhoff, M., Frank, P., Aigner, M.: An experimental and modelling study on the auto ignition of kerosene and surrogate fuel mixture. In: Proc. 46th AIAA Aerospace Sciences Meeting and Exhibit, AIAA-2008-0973 (2008)

4. International Air Transport Association.: http://www.iata.org/ whatwedo/Documents/economics/Industry-Outlook-Jun2012.pdf. Accessed 26 Aug 2015

5. http://www.acare4europe.com/sria/flightpath-2050-goals/protect ing-environment-and-energy-supply-0. Accesses 08 Aug 2015

6. http://ec.europa.eu/transport/modes/air/doc/flightpath2050.pdf. Accessed 24 Aug 2015

7. Advisory Council on Aeronautics Research in Europe (ACARE).: ACARE addendum to the strategic research agenda. http://www. acare4europe.com/sites/acare4europe.org/files/document/ ACARE_2008_Addendum.pdf (2008). Accessed 26 Aug 2015

8. http://www.caafi.org/information/pdf/Path_to_Aviation_Alter native_Fuel_Readiness_May_2013.pdf. (2013)

9. Steele, P., on behalf of ACI, CANSO, ICAO GIACC/3 IATA, ICCAIA, Montreal (Canada), http://www.icao.int/environmentalprotection/GIACC/Giacc-3/Giacc3_Pres_IndustryGoals.pdf. (2009). Accessed 26 Aug 2015

10. Standard D1655.: http://www.astm.org. Accessed 26 Aug 2015

11. https://www.dstan.mod.uk. Accessed 26 Aug 2015

12. Blakey, S., Rye, L., Wilson, C.W.: Aviation gas turbine alternative fuels: a review. Proc. Comb. Inst. 33, 2863-2885 (2011)

13. Braun-Unkhoff, M., Riedel, U.: Alternative fuels in aviation. CEAS Aeronaut. J. 6, 83-93 (2015). doi:10.1007/s13272-014-0131-2

14. Braun-Unkhoff, M., Kathrotia, T., Rauch, B., Riedel, U.: About the interaction between composition and performance of alternative jet fuels. CEAS Aeronaut. J. 7(1), 83-94 (2015). doi:10. 1007/s13272-015-0178-8

15. Kick, Th, Herbst, J., Kathrotia, T., Marquetand, J., BraunUnkhoff, M., Naumann, C., Riedel, U.: An experimental and modeling study of burning velocities of possible future synthetic jet fuels. Energy 43(1), 111-123 (2012)

16. Mzé Ahmed, A., Dagaut, P., Hadj-Ali, K., Dayma, G., Kick, Th, Herbst, J., Kathrotia, T., Braun-Unkhoff, M., Herzler, J., Naumann, C., Riedel, U.: Oxidation of a coal-to-liquid synthetic jet fuel: experimental and chemical kinetic modeling study. Energy Fuels 26(10), 6070-6079 (2012)

17. Dagaut, P., Karsenty, F., Dayma, G., Diévart, P., Hadj-Ali, K., Mzé-Ahmed, A., Braun-Unkhoff, M., Herzler, J., Kathrotia, T., Kick, Th, Naumann, C., Riedel, U., Thomas, L.: Experimental and detailed kinetic model for the oxidation of a gas to liquid (GtL) jet fuel. Combust. Flame 161, 835-847 (2014)

18. Edwards, C., Moses, C., Dryer, F.L.: Evaluation of combustion performance of alternative aviation fuels", 46th AIAA/ASME/ SAE/ASEE Joint Propulsion Conference and Exhibit, Nashville, (USA), AIAA 2010-7155 (2010)

19. FT-fuels approved, announcement, http://www.astmnewsroom. org/default.aspx? ?pageid=1895 (2011). Accessed 26 Aug 2015

20. HEFA approved, announcement, http://www.astmnewsroom.org/ default.aspx?pageid=2524 (2011). Accessed 26 Aug 2015

21. SIP-fuels approved, announcement, http://www.astmnewsroom. org/default.aspx ?pageid=3463 (2014). Accessed 26 Aug 2015

22. burn-FAIR.: LuFO-IV project, http://presse.lufthansa.com/en/ news-releases/singleview/archive/2010/november/29/article/ 1828.html and final report (in German) http://www.aireg.de/ima ges/downloads/Abschlussbericht_BurnFAIR.pdf (2011). Accessed 26 Aug 2015

23. Alfa-BIRD: alternative fuels and biofuels for aircraft, EUFP7/ 2007-2013, Grant agreement No. 213266; co-ordinator: EU-VRi,
(Germany); http://www.alfa-bird.eu-vri.eu. Accessed 26 Aug 2015

24. SWAFEA: Sustainable way for alternative fuels and energy for aviation, EU, DG-TREN, final report, http://www.icao.int/environ mental-protection/GFAAF/Documents/SW_WP9_D.9.1\%20Final\% 20report_released\%20July2011.pdf. Accessed 26 Aug 2015

25. Mosbach, T., Burger, V., Gunasekaran, B.: Fuel influence on targeted gas turbine combustion properties: Part I-detailed diagnostics. In: Proc. ASME Turbo Expo, GT2014-25075, Düsseldorf, Germany (2014)

26. Burger, V., Yates, A., Mosbach, T., Gunasekaran, B.: Fuel influence on targeted gas turbine combustion properties: Part IIdetailed Results. In: Proc. ASME Turbo Expo, GT2014-25105, Düsseldorf, Germany (2014)

27. "Le Clercq, P., Aigner, M.: Impact of alternative fuels physical properties on combustor performance. ICLASS 2009, 11th Trieennial International. Annual Conference on Liquid Atomization and Spray Systems, Vail, USA (2009)

28. Moses, C.A.: Comparison of semi-synthetic jet fuels. CRC Project No. AV-2-04a. Contract. Coordinating Research Council, Inc. (2008). See also http://www.crcao.org. Accessed 26 Aug 2015

29. Le Clercq, P., Di Domenico, M., Rachner, M., Ivanova, E., Aigner, M.: Impact of fischer-tropsch fuels on aero-engine combustion performance," 48th AIAA Aerospace Sciences Meeting, Orlando, Florida, USA, (2010)

30. http://www.aireg.de. Accessed 26 Aug 2015

31. Dagaut, P., Cathonnet, M.: The ignition, oxidation, and combustion of kerosene: a review of experimental and kinetic modeling. Prog. Energ. Combust. 32, 48-92 (2006)

32. Gierens, K., Braun-Unkhoff, M., Le Clercq, P., Plohr, M., Schlager, H., Wolters, F.: Condensation trails from biofuels/kerosene blends scoping study. EU tender, ENER/C2/2013-627, final report (2016)

33. DLR internal report Brennkammermodellierung (BKM) (1998)

34. Böhm, H., Braun-Unkhoff, M.: Numerical study on the effect of oxygenated blending compounds soot formation in shock tubes. Combust. Flame 153, 84-96 (2008)

35. Böhm, H., Braun-Unkhoff, M., Frank, P.: Investigations on initial soot formation at high pressures. Progr. Comp. Fluid Dynam. 3, 145-150 (2003)

36. Hu, D., Braun-Unkhoff, M., Frank, P.: Modeling study on initial soot formation at high pressures. Z. Physik. Chemie. 214(4), 473 (2000)

37. Bockhorn, H. (ed.): Soot formation in combustion, mechanisms and models. Springer, Heidelberg (1994)

38. Wang, H.: Formation of nascent soot and other condensed-phase materials in flames. Proc. Comb. Inst. 31, 41-67 (2011)

39. Eickhoff, H., Braun-Unkhoff, M., El Bakali, A., Frank, P.: Kinetic influences on lean blowout for swirl stabilized combustion. Proc. Comb. Symp. 28, Abstracts of work in progress posters, 366 (2000)

40. Lefebvre, A.H. (ed.): Gas turbine combustion, 2nd edn. Taylor and Francis, London. ISBN: 9781560326731

41. Penner, J., Lister, D., Griggs, D., Dokken, D., McFarland, M. (eds.): Aviation and the global atmosphere. Cambridge University Press, UK, p. 373 (1999)

42. Sausen, R., Isaksen, I., Hauglustaine, D., Grewe, V., Lee, D.S., Myhre, G., Köhler, M.O., Pitari, G., Schumann, U., Stordal, F., Zerefos, C.: Aviation radiative forcing in 2000: an update on IPCC (1999). Meteorol. Z. 14(4), 555-561 (2005)

43. Lee, D.S., Fahey, D.W., Forster, P.M., Newton, P.J., Wit, R.C.N.: Aviation and global climate change in the 21st century. Atmos. Environ. 43(22-23), 3520-3537 (2009)

44. https://www.ipcc.ch/publications_and_data/ar4/wg1/en/ch2s210-2.html (2014). Accessed 26 Aug 2015

45. http://www.world-nuclear.org/info/Energy-and-Environment/Cli mate-Change-The-Science/ (2014). Accessed 26 Aug 2015 
46. Kennedy, I.M.: The health effects of combustion-generated aerosols. Proc. Comb. Inst. 31, 2757-2770 (2007)

47. Schumann, U.: On conditions for contrail formation from aircraft exhausts. Meteorol. Z. 5, 4-23 (1996)

48. Gierens, K.P., Spichtinger, P., Schumann, U.: Ice supersaturation. In: Atmospheric physics. Background-methods-trends, Schumann, U. (Ed.). Springer, Heidelberg 135-150 (2012)

49. Bauldreay, J.M.: Personal communication, Shell Research Ltd, Manchester, UK

50. Moore, R.H., Shook, M., Beyersdorf, A.J., Corr, C., Herndon, S.C., Knighton, W.B., Miake-Lye, R., Thornhill, K.L., Winstead, E., Yu, Z., Ziemba, L.D., Anderson, B.E.: Influence of jet fuel composition on aircraft synthesis of aerosol emissions data from the NASA APEX, AAFEX, and ACCESS missions. Energy Fuels 29(4), 2591-2600 (2015)

51. Bulzan, D., Anderson, B., Wey, C., Howard, R., Winstead, E., Beyersdorf, A., Corporan, E., DeWitt, M.J., Klingshirn, C., Herndon, S., Miake-Lye, R., Timko, M., Wood, E., Tacina, K.M., Liscinsky, D., Hagen, D., Lobo, P., Whitefield, P.: Gaseous and particulate emissions results of the NASA alternative aviation fuel experiment (AAFEX)", Proc. ASME Turbo Expo, Glasgow, United Kingdom, GT2010-23524 (2010)

52. Anderson, B.E., Beyersdorf, A.J., Hudgins, C.H., Plant, J.V., Thornhill, K.L., Winstead, E.L., Ziemba, L.D., Howard, R., Corporan, E., Miake-Lye, R.C., Herndon, S.C., Timko, M., Woods, E., Dodds, W., Lee, B., Santoni, G., Whitefield, P., Hagen, D., Lobo, P., Knighton, W.B., Bulzan, D., Tacina, K., Wey, C., VanderWal, R., Bhargava, A.: Alternative aviation fuel experiment (AAFEX). NASA/TM-2011-217059. National Aeronautics and Space Administration, Hampton (2011)

53. Kinsey, J.S., Timko, M.T., Herndon, S.C., Wood, E.C., Yu, Z., MiakeLye, R.C., Lobo, P., Whitefield, P., Hagen, D., Wey, C., Anderson, B.E., Beyersdorf, A.J., Hudgins, C.H., Thornhill, K.L., Winstead, E., Howard, R., Bulzan, D.I., Tacina, K.B., Berk Knighton, W.: Determination of the emissions from an aircraft auxiliary power unit (APU) during the alternative aviation fuel experiment (AAFEX). J. Air Waste Manag. Asso. 62(4), 420-430 (2012)

54. Lobo, P., Hagen, D.E., Whitefield, P.D.: Comparison of PM emissions from a commercial jet engine burning conventional, biomass, and Fischer-Tropsch fuels. Environ. Sci. Technol. 45(24), 10744-10749 (2011)

55. Emission and CLimate Impact of Alternative Fuels (ECLIF): DLR project (2013-2017)

56. Zschocke, A., Scheuermann, J., Ortner, J.: High biofuel blends in aviation (HBBA). EU tender, ENER/C2/2012/420-1, interim report. http://www.hbba.eu/study/HBBA_Study_Report_6.2. 2015.pdf (2015). Accessed 26 Aug 2015

57. Cain, J., DeWitt, M.J., Blunck, D., Corporan, E., Striebich, R., Anneken, D., Klingshirn, C., Roquemore, W.M., Vander Wal, R.: Characterization of gaseous and particulate emissions from a turboshaft engine burning conventional, alternative, and surrogate fuels. Energy Fuels 27, 2290-2302 (2013)

58. Timko, M.T., Yu, Z., Onasch, T.B., Wong, H.W., Miake-Lye, R.C., Beyersdorf, A.J., Anderson, B.E., Thornhill, K.L., Winstead, E.L., Corporan, E., DeWitt, M.J., Klingshirn, C.D., Wey, C., Tacina, K., Liscinsky, D.S., Howard, R., Bhargava, A.: Particulate emissions of gas turbine engine combustion of a FischerTropsch synthetic fuel. Energy Fuels 24(11), 5883-5896 (2010)

59. DeWitt, M.J., Corporan, E., Graham, J., Minus, D.: Effects of aromatic type and concentration in Fischer-Tropsch fuel on emissions production and material compatibility. Energy Fuels 22 (4), 2411-2418 (2008)

60. Saffaripour, M., Zabeti, P., Kholghy, M.R., Thomson, M.J.: An experimental comparison of the sooting behavior of synthetic jet fuels. Energy Fuels 25, 5584-5593 (2011)
61. Saffaripour, M., Veshkini, A., Kholghy, M.R., Thomson, M.J.: Experimental investigation and detailed modeling of soot aggregate formation and size distribution in laminar coflow diffusion flames of Jet A-1, a synthetic kerosene, and $n$-decane. Comb. Flame 161 (3), 848-863 (2014)

62. Wahl, C., Zornek, T., Kapernaum, M., Haslach, L., Zschocke, A., Mroch, M., Demoment, P., Rolland, O., Garcia, F.: Engine emission ground test with Jet A-1/Farnesane blends. In: Proc. 18th ETH Conference on combustion generated nanoparticles, ETH Zürich, Switzerland (2014)

63. Wahl, C., Kapernaum, M., Melkert, J., Snijders, T., Bauldreay, J., Bogers, P.: Nanoparticle emissions of a flight gas turbine running Jet A-1 and GTL mixtures. In: Proc. 17th ETH Conference on combustion generated nanoparticles, ETH Zürich, Switzerland (2013)

64. Snijders, T.A., Melkert, J.A., Bauldreay, J.M, Bogers, P., Wahl, C.R.M., Kapernaum, M.G.: Impact of fuel composition on emissions and performance of GTL kerosine blends in a cessna citation II. In: Proc. 12th Internat. Conference on Stability Handling and Use of Liquid Fuels, IASH, Atlanta, GA (2011)

65. Wahl, C., Aigner, M.: Aircraft gas turbine soot emission tests under technical relevant conditions in an altitude test facility., In: Proc. ASME Turbo Expo GT2003-38797, Atlanta, USA (2003)

66. Altaher, M., Li, H., Blakey, S., Chung, W.: NHMC and VOC speciation of the exhaust gas from a gas turbine using alternative, renewable and conventional Jet A-1 aviation fuels. In: Proc. ASME Turbo Expo GT2014-25445, Düsseldorf, Germany (2014)

67. Li, H., Altaher, M., Wilson, C., Blakey, S., Chung, W.: Influence of fuel composition, engine power and operation mode on exhaust gas particulate size distribution and gaseous emissions form a gas turbine engine. In: Proc. ASME Turbo Expo GT201394854, San Antonio, Texas, USA (2013)

68. Lobo, P., Rye, L., Williams, P.I., Christie, S., Uryga-Bugajska, I., Wilson, C.W., Hagen, D.E., Whitefield, P.D., Blakey, S., Coe, H., Raper, D., Pourkashanian, M.: Impact of alternative fuels on emission characteristics of a gas turbine engine-Part 1: gaseous and particulate matter emissions. Environ. Sci. Technol. 46, 10805-10811 (2012)

69. Christie, S., Raper, D., Lee, D.S., Williams, P.I., Rye, L., Blakey, S., Wilson, C.W., Lobo, P., Hagen, D., Whitefield, P.D.: Polycyclic aromatic hydrocarbon emissions from the combustion of alternative fuels in a gas turbine engine. Environ. Sci. Technol. 46, 6393-6400 (2012)

70. Bhagwan, R., Habisreuther, P., Zarzalis, N., Turrini, F.: An experimental comparison of the emissions characteristics of standard Jet A-1 and synthetic fuels. Flow Turbulence Combust. 92, 865-884 (2014)

71. Rahmes, S.T.F., Kinder, J.D., Henry, T.M., et al.: Sustainable bio-derived synthetic paraffinic kerosene (Bio-spk) jet fuel flights and engine test program results. Ninth AIAA Aviation Technology, Integration, and Operations Conference (ATIO), AIAA, Hilton Head, South Carolina, USA (2009)

72. Riebl, S., Braun-Unkhoff, M., Riedel, U.: A study on the emissions of alternative aviation fuels. In: Proc. ASME Turbo Expo, GT2016-57361, Seoul, South Korea (2016)

73. Wahl, C., Kapernaum, M., Krüger, V., Rainer, P., Aigner, M., Determination of soot mass fraction, soot density, and soot fractal character in flame exhaust gases (PAZI). EUR 21051-European Conference on Aviation, Atmosphere and Climate (AAC), Air pollution research report 83, 25-26 (2004)

74. Andrade-Eiroa, A., Shahla, R., Romanías, M.N., Dagaut, P., Emmanouil, K.S., Apostolos, S., Dayma, G.: Identification and quantification of aromatic hydrocarbons adsorbed on soot from premixed flames of kerosene, synthetic kerosene, and kerosenesynthetic biofuels. Energy Fuels 29 (10), 6556-6564 (2015) 